This document is confidential and is proprietary to the American Chemical Society and its authors. Do not copy or disclose without written permission. If you have received this item in error, notify the sender and delete all copies.

\title{
Pathway Diversity in the Self-Assembly of DNA-Derived Bioconjugates
}

\begin{tabular}{|r|l|}
\hline Journal: & Bioconjugate Chemistry \\
\hline Manuscript ID & bc-2016-00517a.R1 \\
\hline Manuscript Type: & Article \\
\hline Date Submitted by the Author: & $\mathrm{n} / \mathrm{a}$ \\
\hline Complete List of Authors: & $\begin{array}{l}\text { Vyborna, Yuliia; University of Bern, Department of Chemistry and } \\
\text { Biochemistry } \\
\text { Vybornyi, Mykhailo; Technische Universiteit Eindhoven, Institute of } \\
\text { Complex Molecular Systems } \\
\text { Häner, Robert; University of Bern, Department of Chemistry and } \\
\text { Biochemistry }\end{array}$ \\
\hline
\end{tabular}

SCHOLARONE ${ }^{\mathrm{m}}$

Manuscripts 


\title{
Pathway Diversity in the Self-Assembly of DNA-
}

\section{Derived Bioconjugates}

\author{
Yuliia Vyborna ${ }^{a}$, Mykhailo Vybornyi $^{b}$ and Robert Häner ${ }^{a} *$ \\ ${ }^{a}$ Department of Chemistry and Biochemistry, University of Bern, Freiestrasse 3, CH-3012 Bern, Switzerland \\ robert.haener@dcb.unibe.ch \\ ${ }^{\mathrm{b}}$ Present Adress: Institute of Complex Molecular Systems, Laboratory of Macromolecular and Organic Chemistry, Eindhoven University \\ of Technology, P.O. Box 513, 5600 MB Eindhoven, The Netherlands.
}

RECEIVED DATE (to be automatically inserted after your manuscript is accepted if required according to the journal that you are submitting your paper to) 


\begin{abstract}
The pathway diversity of the self-assembly of amphiphilic DNA-pyrene conjugates is described. The hydrophobic pyrene units drive the self-assembly of the anionic oligomers in an aqueous environment into ribbon-shaped, DNA-grafted supramolecular polymers. Isothermal mixing of two types of sorted ribbons, each of which contains only one kind of two complementary oligonucleotides, results in the formation of tight networks. Thermal disassembly of these kinetically trapped networks and subsequent re-assembly of the liberated components leads to mixed supramolecular polymers, which now contain both types of oligonucleotides. The scrambling of the oligonucleotides prevents the interaction between ribbons and, thus, network formation. The results show that a high local density of DNA strands in linear arrays favors hybridization among sorted polymers, whereas hybridization among mixed arrays is prevented. The lack of DNA hybridization among mixed ribbons is ascribed to the electrostatic repulsion between identical, hence non-complementary, oligonucleotides. The findings highlight the importance of kinetically trapped states on the structural and functional properties of supramolecular polymers containing orthogonal self-assembly motifs.
\end{abstract}




\section{INTRODUCTION}

Supramolecular polymers provide direct access to a large diversity of functional materials due to their dynamic nature, their responsiveness to external stimuli as well as the tunability and reversibility of the noncovalent interactions governing their assembly. ${ }^{1,2}$ A thorough understanding of the self-assembly pathways is essential for extending the functionalities of these materials. ${ }^{3-7}$ Directing the noncovalent interactions allows controlling the properties of the resulting supramolecular constructs. ${ }^{8-12}$ In addition, the proper choice of assembly protocols helps in tuning the properties of biomaterials ${ }^{13}$ or improves the performance of organic semiconductors. ${ }^{14}$ Thus, the chemical composition alone is often insufficient to achieve the best performance of complex supramolecular assemblies, among which DNA-based materials take a prominent role. ${ }^{15}$ DNA-assembled objects are of interest in the design and development of drug carriers, nanomachines, and other types of sophisticated nanomaterials. ${ }^{16-21}$ The wide range of potential applications has led to considerable interest in the properties of oligonucleotides conjugated to polymers or lipophilic chains. ${ }^{22-30}$ DNA conjugates often combine multiple self-assembly motifs enabling selective and orthogonal noncovalent interactions. ${ }^{31-37}$ To date, little is known about materials from DNA conjugates, in which the interactions between the non-DNA parts are central for the hierarchical organization. Therefore, the study of the mechanistic details of self-assembly in such systems is important. The characterization of individual processes leading to morphologically different products, as well as the identification of escape pathways from kinetically trapped states into the thermodynamically favored structure, are of special interest. Recently, we have reported on the synthesis of one-dimensional DNA-grafted supramolecular polymers ${ }^{38,39}$ using short, chimeric DNA-pyrene oligomers. ${ }^{40,41}$ Here, we describe different competitive aggregation pathways of these oligomers and highlight the importance of kinetically trapped states for the controlled self-assembly of DNA hybrid materials. 


\section{RESULTS AND DISCUSSION}

Two-component system - We will first describe a two-component system consisting of two chimeric oligomers, Py-a and Py-b (Scheme 1). Both oligomers were synthesized by solid phase synthesis. They contain the same heptapyrenotide ${ }^{42}$ segment but different DNA sequences. The pyrenotide part, which consists of seven phosphodiester-linked 1,6-dialkynyl substituted pyrenes, is conjugated to the $5^{`}$-end of a 10-mer DNA sequence (Scheme 1). The DNA sequences of Py-a and Py-b are complementary. As established before ${ }^{38}$ the oligomers self-assemble in an aqueous medium into one-dimensional (1D) ribbon-like supramolecular polymers via stacking interactions between pyrene units (Scheme 2). The ribbons consist of a pyrene core with DNA single strands tethered along the edges.

Scheme 1. Chemical structure of pyrene-DNA chimeric oligomers, sequences used in the current study and illustration of oligomers Py-a and Py-b.

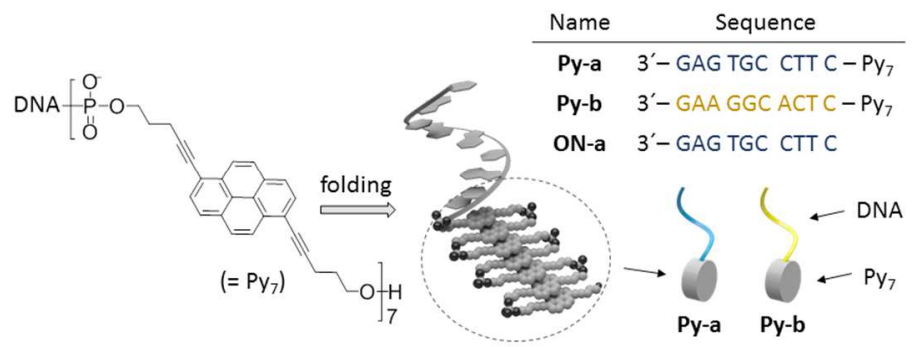


Scheme 2. Schematic illustration of the self-assembly pathways of pyrene-DNA hybrids into onedimensional DNA-grafted supramolecular polymers and networks.

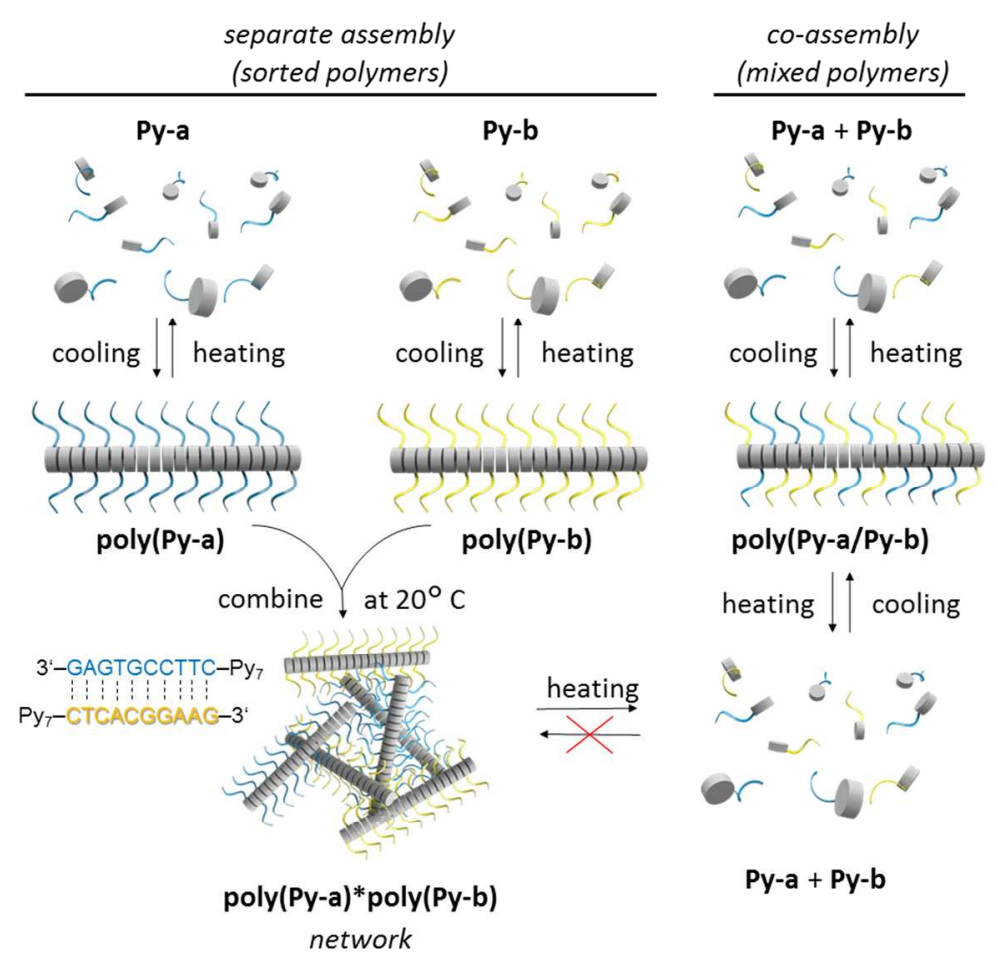

The supramolecular polymers are prepared by cooling a solution of oligomers Py-a and/or Py-b from $95^{\circ} \mathrm{C}$ to $20{ }^{\circ} \mathrm{C}$ using a temperature gradient of $0.1{ }^{\circ} \mathrm{C} / \mathrm{min}$. At $95^{\circ} \mathrm{C}$, the oligomers are dissolved. The slow cooling gradient ensures that the self-assembly process takes place at or near the thermodynamic equilibrium. Nucleation starts around $80{ }^{\circ} \mathrm{C}$ and is followed by a cooperative elongation process. The objects obtained via co-annealing of $\mathbf{P y - a}$ and $\mathbf{P y}-\mathbf{b}$ to give poly(Py-a/Py-b) are morphologically indistinguishable from the ones obtained in the single-component systems poly(Py-a) or poly(Py-b), which are prepared from the respective monomer solutions (Supporting Information Figure S2). Isothermal mixing of equal quantities of the separately prepared, sorted poly(Py-a) and poly(Py-b) results in the formation of poly(Py-a)*poly(Py-b) networks through base pairing as illustrated in Scheme 2. Poly(Py$\mathbf{a} / \mathbf{P y}-\mathbf{b})$, on the other hand, does not form this type of networks although these polymers are quantita- 
tively composed of the same components. Figure 1 shows typical atomic force microscopy (AFM) images of poly(Py-a/Py-b) copolymers and poly(Py-a)*poly(Py-b) networks.
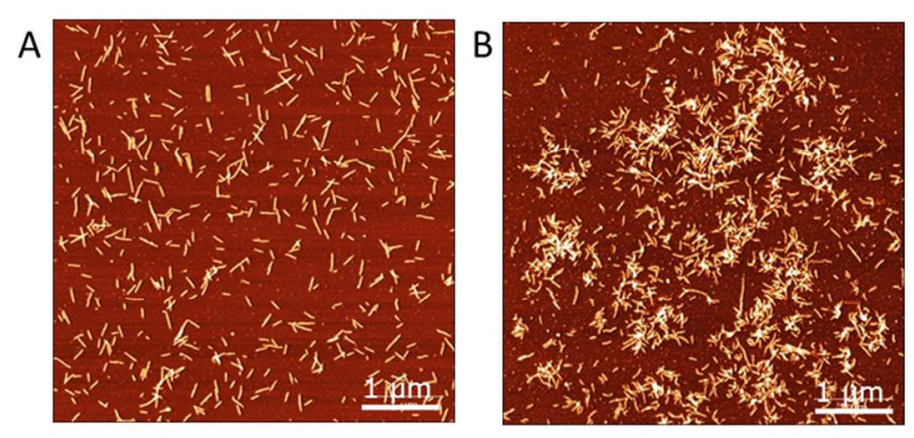

Figure 1. Representative AFM images of discrete ribbons poly(Py-a/Py-b) (A) and interconnected polymer networks poly(Py-a)*poly(Py-b) (B). Conditions: $200 \mathrm{mM} \mathrm{NaCl,} 10 \mathrm{mM}$ phosphate buffer system $\mathrm{pH}=7$, concentration of each oligomer $=2 \mu \mathrm{M}$.

Figure 2 shows the disassembly-reassembly cycles of poly(Py-a)* poly(Py-b) (kinetically trapped product) and poly(Py-a/Py-b) (thermodynamically favored product) monitored by temperature dependent intensity changes at $305 \mathrm{~nm}$. This wavelength corresponds to the maximum of the absorption band for the aggregated pyrenes (J-band) and serves as a reliable indicator of the aggregation state of pyrenes. ${ }^{43}$ Upon slowly heating to $95{ }^{\circ} \mathrm{C}$, both poly(Py-a)*poly(Py-b) and poly(Py-a/Py-b) disassemble into molecularly dissolved Py-a and Py-b chains as indicated by the complete disappearance of the Jband (Figure 2C). However, the normalized heating curves (red lines in Figures 2A and 2B) exhibit a similar shape only in the range from $65^{\circ} \mathrm{C}$ to $95^{\circ} \mathrm{C}$. Below $65^{\circ} \mathrm{C}$, the pyrene absorbance of poly(Pya)*poly(Py-b) reveals competing processes which occur in the course of the heating event (Figure 2B). The initial gradual decrease in absorption from 20 to $50^{\circ} \mathrm{C}$ is probably due to sedimentation of large network aggregates. ${ }^{44}$ Between 50 and $65^{\circ} \mathrm{C}$, a stepwise recovery of the signal takes place until the same value is reached as in the heating curve (cf. Figure 2A) of the mixed polymer poly(Py-a/Py-b). Above $65^{\circ} \mathrm{C}$, the decrease of the absorbance reflects the disassembly of pyrenes solely, which is reflect- 
ed by identical shapes of the melting curves of both, poly(Py-a)*poly(Py-b) and poly(Py-a/Py-b). Renewed slow cooling of the obtained molecularly dissolved chains from $95{ }^{\circ} \mathrm{C}$ to $20{ }^{\circ} \mathrm{C}$ leads in both cases to the formation of the mixed polymer $\mathbf{p o l y}(\mathbf{P y}-\mathbf{a} / \mathbf{P y}-\mathbf{b})$ in a cooperative process.
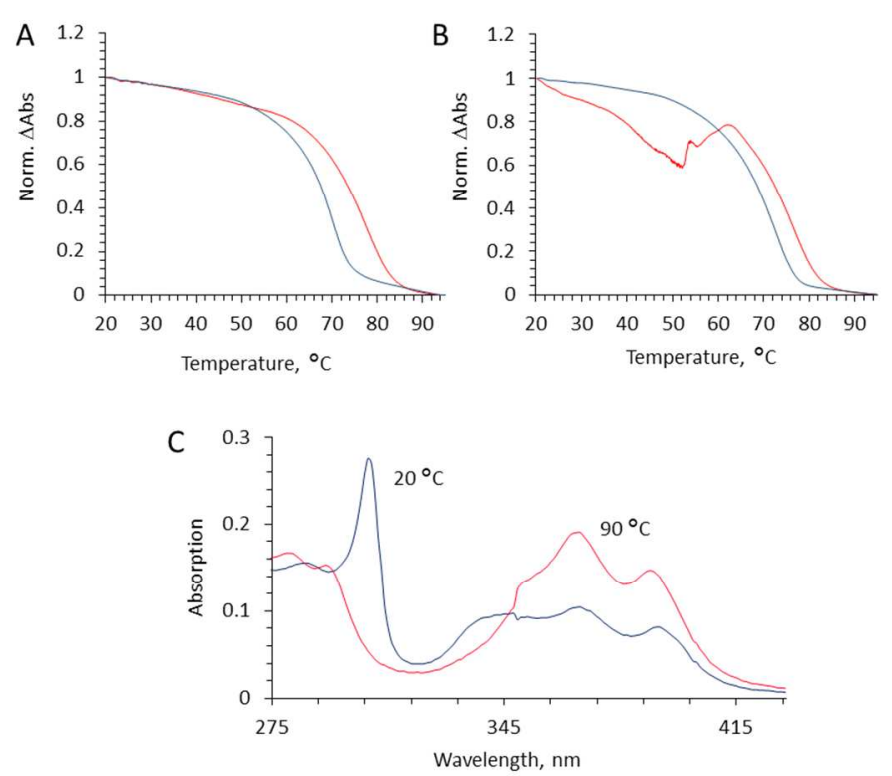

Figure 2. Normalized temperature-dependent change of absorption measured at $305 \mathrm{~nm}$ for poly(Pya/Py-b) (A) and poly(Py-a)*poly(Py-b) (B). Heating (red) and cooling (blue) were performed using a gradient of $0.1^{\circ} \mathrm{C} / \mathrm{min}$. (C) UV-vis spectra for poly(Py-a)* poly(Py-b). For experimental conditions, see Figure1.

The disassembly process of the networks was further studied by performing additional heating-cooling experiments and analyzing the morphology of the newly formed aggregates by AFM at $20{ }^{\circ} \mathrm{C}$. The experiments consisted of heating $\mathbf{p o l y}(\mathbf{P y}-\mathbf{a})^{*} \mathbf{p o l y}(\mathbf{P y}-\mathbf{b})$ from $20^{\circ} \mathrm{C}$ to a certain temperature $T$ and cooling it back to $20^{\circ} \mathrm{C}$. The observed morphology turned out to be highly dependent on $T$. For example, heating to $T=35^{\circ} \mathrm{C}$ and further cooling to $20^{\circ} \mathrm{C}$ results in the exclusive formation of large and tightly packed networks (Figure 3A). Apparently, increasing the temperature to $35^{\circ} \mathrm{C}$ seems to favor the interactions between individual ribbons. Sedimentation of the large aggregates would explain the decrease in absorption. Heating poly(Py-a)* poly(Py-b) to $T=55^{\circ} \mathrm{C}$, which is still in a region with a descending 
pyrene absorption, led to the formation of networks together with short polymers (Figure 3B). This indicates the partial dissolution of the large networks at this temperature liberating individual Py-a and Py-b oligomers, which subsequently reassemble into mixed polymers poly(Py-a/Py-b). Heating to $75{ }^{\circ} \mathrm{C}$ yielded morphologically similar structures as the experiment conducted to $T=55^{\circ} \mathrm{C}$ (Figure 3C). Finally, at $T=95{ }^{\circ} \mathrm{C}$, the networks are completely disassembled, which is demonstrated by the exclusive formation of $\mathbf{p o l y}(\mathbf{P y}-\mathbf{a} / \mathbf{P y}-\mathbf{b})$ after reassembly; no networks could be detected (Figure 3D). These results imply that the networks are metastable and rearrange into thermodynamically favored 1D supramolecular polymers in a temperature-induced disassembly-assembly process.

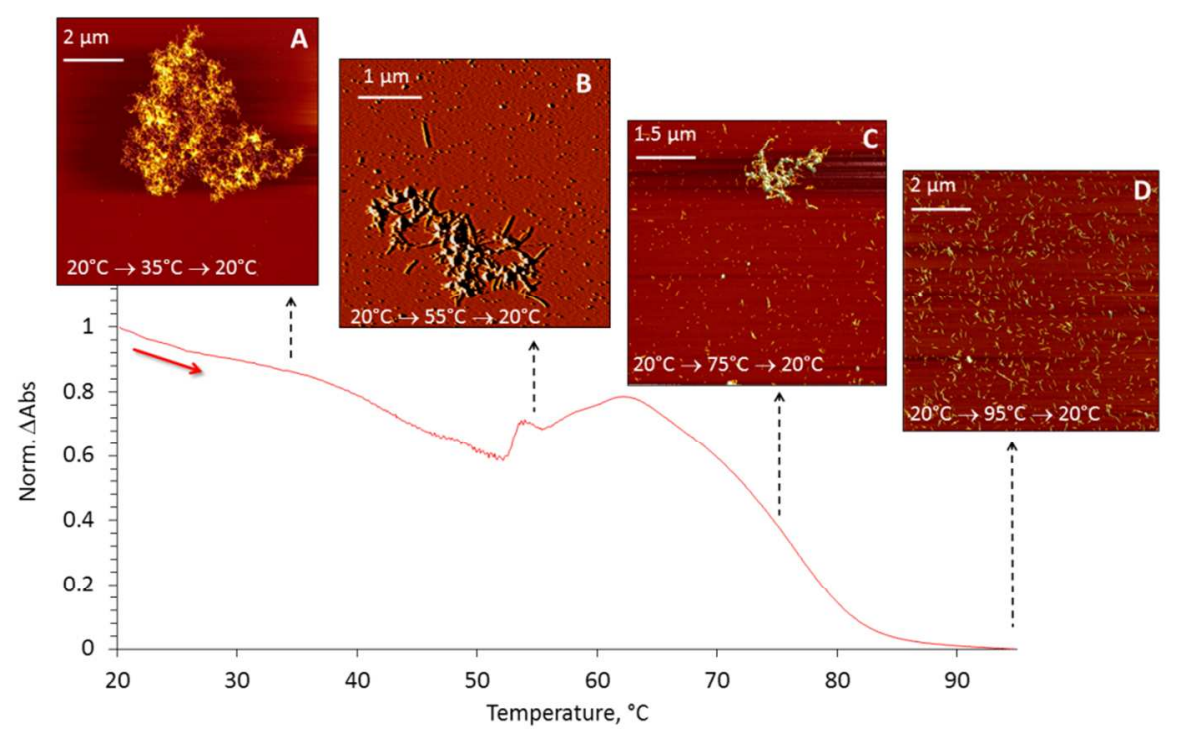

Figure 3. Melting curve and AFM images of materials obtained upon applying heating-cooling cycles (for more details see main text) to poly(Py-a)*poly(Py-b). Conditions see Figure 1.

Scheme 2 summarizes the processes occurring in the two-component system. On the one hand, the separate self-assembly of Py-a and Py-b leads to linear poly(Py-a) and poly(Py-b). Mixing these two types of sorted, supramolecular polymers at $20{ }^{\circ} \mathrm{C}$ results in the formation of metastable networks poly(Py-a)*poly(Py-b), in which individual ribbons are interconnected by DNA hybridization. These aggregates are converted by sequential thermal denaturation and reassembly into the thermodynamically 
favored poly(Py-a/Py-b), which has mixed DNA strands and, thus, forms only one-dimensional supramolecular polymers but no networks. The absence of networks is rationalized by the electrostatic repulsion between non-complementary DNA strands. ${ }^{45,46}$ On the other hand, the hybridization of complementary DNAs between sorted ribbons, poly(Py-a) and poly(Py-b), leads to the networks observed for poly(Py-a)*poly(Py-b). Multiple sites of interactions between individual ribbons render the aggregation process highly cooperative. The results show that individual oligomers $\mathbf{P y - a}$ and $\mathbf{P y}-\mathbf{b}$ remain kinetically trapped in poly(Py-a)*poly(Py-b) and only thermal activation allows their transformation into the energetically more favored product. We tested the property of poly(Py-a)*poly(Py-b) and poly(Pya/Py-b) to entrap hydrophobic molecules using Nile Red as a fluorescent reporter. The emission spectra show that both linear supramolecular polymers and networks accommodate the dye in their hydrophobic environments (see Supporting Information).

Three-component system - In addition to $\mathbf{P y - a}$ and $\mathbf{P y - b}$, the three-component system also involves oligonucleotide ON-a, which is complementary to Py-b (Scheme 1). AFM imaging shows that the addition of $\mathbf{O N}$-a to preformed $\mathbf{p o l y}(\mathbf{P y}-\mathbf{a}) * \operatorname{poly}(\mathbf{P y}-\mathbf{b})$ at $20^{\circ} \mathrm{C}$ does not have an effect on the appearance of the networks (Figure 4B, C). As previously shown, the addition of $\mathbf{O N}$-a to poly(Py-b) also leads to the formation of networks (poly(Py-b)* $\mathbf{O N - a}) .{ }^{39}$ These networks, however, are formed via blunt-end interactions $^{47,48}$ (see Figure 5). That type of network is structurally different and can be distinguished spectroscopically from poly(Py-a)*poly(Py-b). CD spectroscopy (Supporting Information, Figure S1) confirms that the latter type of network originates from DNA hybridization and not blunt-end interactions. Disassembly of these aggregates $\left(\mathbf{p o l y}(\mathbf{P y}-\mathbf{a})^{*} \mathbf{p o l y}(\mathbf{P y}-\mathbf{b})+\mathbf{O N}-\mathbf{a}\right)$ by heating to $95{ }^{\circ} \mathrm{C}$ leads to the molecularly dissolved chains comparable to the two-component system (Figure 6A). Renewed cooling from $95^{\circ} \mathrm{C}$ to $20^{\circ} \mathrm{C}$ exhibits a single transition in accordance with a nucleation-elongation mechanism and exclusively leads to linear supramolecular polymers (Figure 4D). Next, poly(Py-b) and ON-a were mixed to form networks of poly(Py-b)* ON-a as confirmed by AFM (Figure 5B) and CD analysis (Supporting Information, Figure S1). 

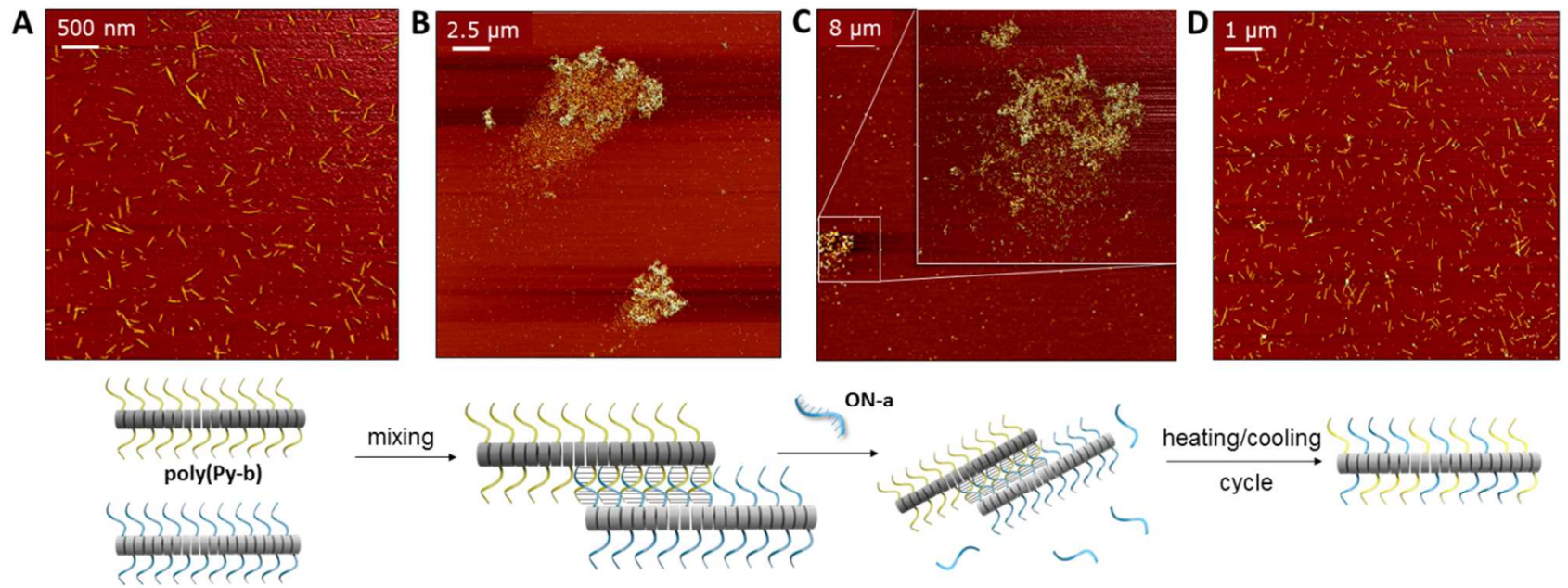

poly(Py-a)

poly $(\mathrm{Py}-\mathrm{a})^{*}$ poly(Py-b)

poly $(\mathrm{Py}-\mathrm{a})^{*}$ poly $(\mathrm{Py}-\mathrm{b})+\mathrm{ON}-\mathrm{a}$

poly $(\mathrm{Py}-\mathrm{a} / \mathrm{Py}-\mathrm{b})+\mathrm{ON}-\mathrm{a}$

Figure 4. AFM images of materials obtained at different stages in a three-component mixture using poly $(\mathbf{P y}-\mathbf{a}) * \operatorname{poly}(\mathbf{P y}-\mathbf{b})$ networks. Conditions see Figure 1.
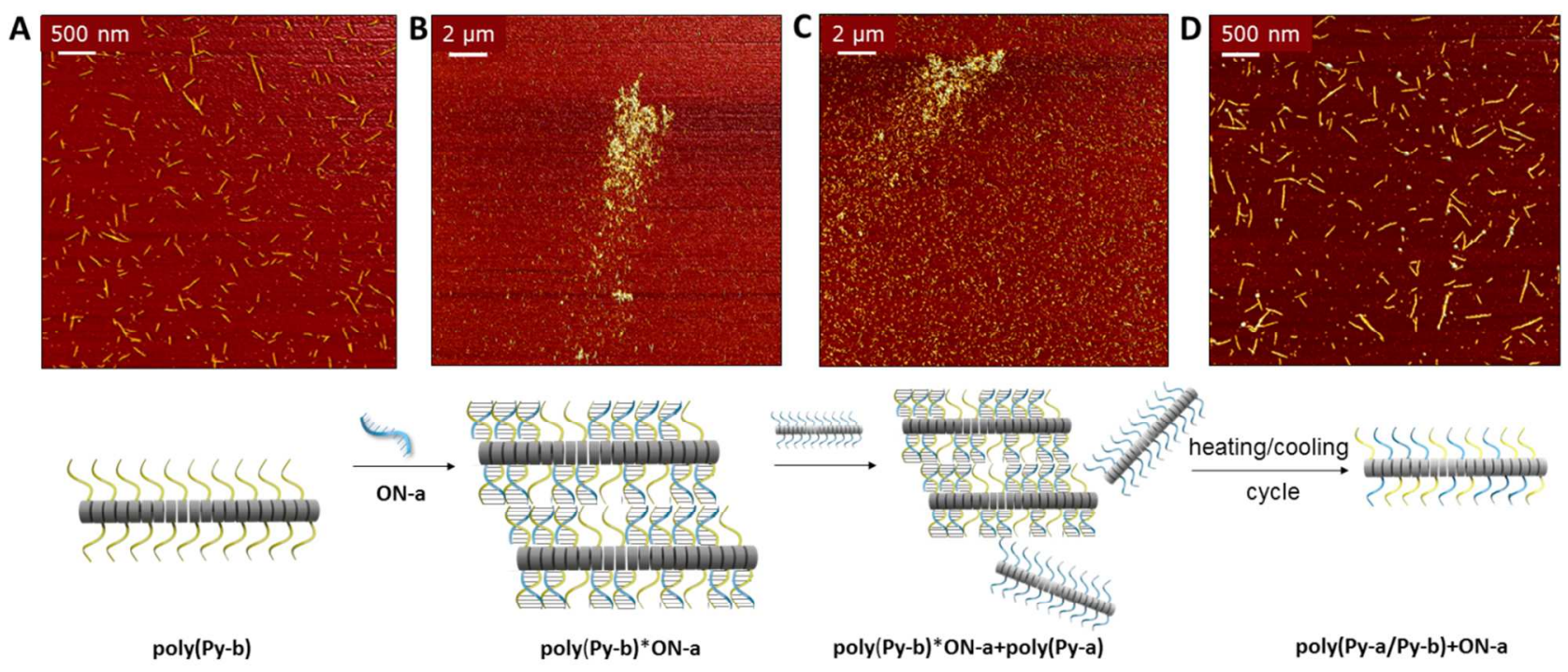

heating/cooling

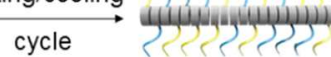

Figure 5. AFM images of materials obtained at different stages in a three-component mixture using poly(Py-b)*ON-a networks. Conditions see Figure 1. 

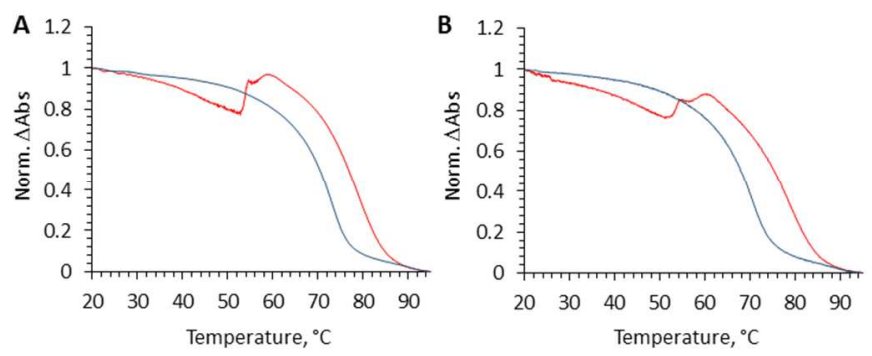

Figure 6. Normalized temperature-dependent absorption measured at $305 \mathrm{~nm}$ for poly(Py-a)*poly(Pyb)+ON-a (A) and poly(Py-b)* ON-a+poly(Py-a) (B). Conditions: see Figure 1.

After addition of poly(Py-a) to this system, AFM images show the presence of both, poly(Py-b)* ONa networks and linear poly(Py-a) (Figure 5C). This indicates that hybridization of DNA chains of poly(Py-b) with $\mathbf{O N - a}$ precludes duplex formation between complementary strands of $\mathbf{p o l y}(\mathbf{P y}-\mathbf{a})$ and poly(Py-b). This underlines the slow dynamics of hybrid oligomer exchange. Performing an additional heating/cooling cycle (Figure 6B) leads again to the formation of the thermodynamically favored, mixed supramolecular polymers (Figure 5D).

\section{CONCLUSIONS}

The pathway complexity of the self-assembly in systems containing pyrene-DNA conjugates Py-a and $\mathbf{P y}-\mathbf{b}$ has been elucidated. Supramolecular polymerization of a mixture of equal amounts of Py-a and $\mathbf{P y}-\mathbf{b}$ leads to the formation of $\mathbf{p o l y}(\mathbf{P y}-\mathbf{a} / \mathbf{P y}-\mathbf{b})$. These mixed polymers contain both types of complementary DNA strands arranged along their edges and network formation is completely prevented. Alternatively, combining the separately prepared, sorted polymers poly(Py-a) and poly(Py-b) leads to the formation of metastable networks via crosslinking of individual ribbons by DNA hybridization. The networks are stable at room temperature due to a slow rate of oligomer exchange between the polymers. However, temperature induced disassembly of the networks and subsequent reannealing of the released oligomers Py-a and $\mathbf{P y}-\mathbf{b}$ results in the formation of the thermodynamically preferred mixed polymer 
poly(Py-a/Py-b), which does not form networks. The lack of DNA hybridization among ribbons of

poly $(\mathbf{P y}-\mathbf{a} / \mathbf{P y}-\mathbf{b})$ is ascribed to the electrostatic repulsion between identical, hence non-complementary, oligonucleotides that are present in a high density at the edges of the polymeric ribbons. The findings illustrate the importance of kinetically trapped states on the structural and functional properties of supramolecular polymers.

\section{ASSOCIATED CONTENT}

The supporting information is available free of charge via the Internet at http://pubs.acs.org.

Materials and general methods; CD and fluorescence spectra; additional AFM images.

\section{NOTES}

The authors declare no competing financial interest.

\section{FUNDING SOURCES}

This work was supported by the Swiss National Foundation (Grant 200020-149148).

\section{REFERENCES}

(1) Webber, M. J.; Appel, E. A.; Meijer, E. W.; Langer, R. (2016) Supramolecular Biomaterials. Nat. Mater. 15, 13-26.

(2) Krieg, E.; Bastings, M. M. C.; Besenius, P.; Rybtchinski, B. (2016) Supramolecular Polymers in Aqueous Media. Chem. Rev. 116, 2414-2477.

(3) Korevaar, P. A.; De Greef, T. F.; Meijer, E. (2014) Pathway Complexity in Pi-Conjugated Materials. Chem. Mater. 26, 576-586.

(4) Ogi, S.; Sugiyasu, K.; Manna, S.; Samitsu, S.; Takeuchi, M. (2014) Living Supramolecular Polymerization Realized Through a Biomimetic Approach. Nat. Chem. 6, 188-195.

(5) Elio, M.; Sijbren, O. (2015) Supramolecular Systems Chemistry. Nat. Nanotech. 10, 111-119.

(6) Lutz, J. F.; Lehn, J. M.; Meijer, E. W.; Matyjaszewski, K. (2016) From Precision Polymers to Complex Materials and Systems. Nat. Rev. Mater. 1.

(7) Lutz, J. F.; Börner, H. G. (20o8) Modern Trends in Polymer Bioconjugates Design. Prog. Polym. Sci. 33, 1-39.

(8) Boekhoven, J.; Poolman, J. M.; Maity, C.; Li, F.; van der Mee, L.; Minkenberg, C. B.; Mendes, E.; van, E. H.; Eelkema, R. (2013) Catalytic Control Over Supramolecular Gel Formation. Nat. Chem. 5, 433-437. 
(9) Cheng, C.; McGonigal, P. R.; Stoddart, J. F.; Astumian, R. D. (2015) Design and Synthesis of Nonequilibrium Systems. ACS Nano 9, 8672-8688.

(10) Erbas-Cakmak, S.; Leigh, D. A.; McTernan, C. T.; Nussbaumer, A. L. (2015) Artificial Molecular Machines. Chem. Rev. 115, 10081-10206.

(11) Ogi, S.; Stepanenko, V.; Thein, J.; Würthner, F. (2016) Impact of Alkyl Spacer Length on Aggregation Pathways in Kinetically Controlled Supramolecular Polymerization. J. Am. Chem. Soc. 138, 670-678.

(12) Baram, J.; Weissman, H.; Rybtchinski, B. (2014) Supramolecular Polymer Transformation: a Kinetic Study. J. Phys. Chem. B 118, 12068-12073.

(13) Tantakitti, F.; Boekhoven, J.; Wang, X.; Kazantsev, R. V.; Yu, T.; Li, J.; Zhuang, E.; Zandi, R.; Ortony, J. H.; Newcomb, C. J. et al. (2016) Energy Landscapes and Functions of Supramolecular Systems. Nat. Mater. 15, 469-476.

(14) Henson, Z. B.; Müllen, K.; Bazan, G. C. (2012) Design Strategies for Organic Semiconductors Beyond the Molecular Formula. Nat. Chem. 4, 699-704.

(15) Jones, M. R.; Seeman, N. C.; Mirkin, C. A. (2015) Programmable Materials and the Nature of the DNA Bond. Science 347, 1260901.

(16) Seeman, N. C. (2010) Nanomaterials Based on DNA. Annu. Rev. Biochem. 79, 65-87.

(17) Rothemund, P. W. K. (2006) Folding DNA to Create Nanoscale Shapes and Patterns. Nature 440, 297-302.

(18) Endo, M.; Sugiyama, H. (2014) Single-Molecule Imaging of Dynamic Motions of Biomolecules in DNA Origami Nanostructures Using High-Speed Atomic Force Microscopy. Acc. Chem. Res. 47, 1645-1653.

(19) Sacca, B.; Niemeyer, C. M. (2012) DNA Origami: The Art of Folding DNA. Angew. Chem. Int. Ed. 51, 58-66.

(20) Yang, Y.; Wang, J.; Shigematsu, H.; Xu, W.; Shih, W. M.; Rothman, J. E.; Lin, C. (2016) SelfAssembly of Size-Controlled Liposomes on DNA Nanotemplates. Nat. Chem. 8, 476-483.

(21) Li, J.; Mo, L.; Lu, C. H.; Fu, T.; Yang, H. H.; Tan, W. (2016) Functional Nucleic Acid-Based Hydrogels for Bioanalytical and Biomedical Applications. Chem. Soc. Rev. 45, 1410-1431.

(22) de Rochambeau, D.; Barlog, M.; Edwardson, T. G. W.; Fakhoury, J. J.; Stein, R. S.; Bazzi, H. S.; Sleiman, H. F. (2016) "DNA-Teflon" Sequence-Controlled Polymers. Polym. Chem. 7, 4998-5003.

(23) Schade, M.; Berti, D.; Huster, D.; Herrmann, A.; Arbuzova, A. (2014) Lipophilic Nucleic Acids - A Flexible Construction Kit for Organization and Functionalization of Surfaces. Adv. Colloid. Interface Sci. 208, 235-251.

(24) Banga, R. J.; Chernyak, N.; Narayan, S. P.; Nguyen, S. T.; Mirkin, C. A. (2014) Liposomal Spherical Nucleic Acids. J. Am. Chem. Soc. 136, 9866-9869.

(25) Peng, L.; Wu, S.; You, M.; Han, D.; Chen, Y.; Fu, T.; Tan, W. (2013) Engineering and Applications of DNA-Grafted Polymer. Chem. Sci. 4, 1928-1938.

(26) Rush, A. M.; Thompson, M. P.; Tatro, E. T.; Gianneschi, N. C. (2013) Nuclease-Resistant DNA Via High-Density Packing in Polymeric Micellar Nanoparticle Coronas. Acs Nano 7, 1379-1387.

(27) Luo, Q.; Shi, Z.; Zhang, Y.; Chen, X. J.; Han, S. Y.; Baumgart, T.; Chenoweth, D. M.; Park, S. J. (2016) DNA Island Formation on Binary Block Copolymer Vesicles. J. Am. Chem. Soc. 10157-10162.

(28) Kwak, M.; Herrmann, A. (2011) Nucleic Acid Amphiphiles: Synthesis and Self-Assembled Nanostructures. Chem. Soc. Rev. 40, 5745-5755. 
(29) Wu, F.; Song, Y.; Zhao, Z.; Zhang, S.; Yang, Z.; Li, Z.; Li, M.; Fan, Q. H.; Liu, D. (2015) Preparation and Self-Assembly of Supramolecular Coil-Rod-Coil Triblock Copolymer PPODsDNA-PPO. Macromol. 48, 7550-7556.

(30) Patwa, A.; Gissot, A.; Bestel, I.; Barthelemy, P. (2011) Hybrid Lipid Oligonucleotide Conjugates: Synthesis, Self-Assemblies and Biomedical Applications. Chem. Soc. Rev. 40, 5844-5854.

(31) Serpell, C. J.; Edwardson, T. G.; Chidchob, P.; Carneiro, K. M.; Sleiman, H. F. (2014) Precision Polymers and 3D DNA Nanostructures: Emergent Assemblies From New Parameter Space. J. Am. Chem. Soc. 136, 15767-15774.

(32) Jakobsen, U.; Simonsen, A. C.; Vogel, S. (2008) DNA-Controlled Assembly of Soft Nanoparticles. J. Am. Chem. Soc. 130, 10462-10463.

(33) Beales, P.; Geerts, N.; Inampudi, K. K.; Shigematsu, H.; Wilson, C. J.; Vanderlick, T. K. (2013) Reversible Assembly of Stacked Membrane Nanodiscs With Reduced Dimensionality and Variable Periodicity. J. Am. Chem. Soc. 135, 3335-3358.

(34) Hernandez-Ainsa, S.; Ricci, M.; Hilton, L.; Avino, A.; Eritja, R.; Keyser, U. F. (2016) Controlling the Reversible Assembly of Liposomes Through a Multistimuli Responsive Anchored DNA. Nano Lett. 16, 4462-4466.

(35) Knudsen, J. B.; Liu, L.; Kodal, A. L. B.; Madsen, M.; Li, Q.; Song, J.; Woehrstein, J. B.; Wickham, S. F.; Strauss, M. T.; Schueder, F. et al. (2015) Routing of Individual Polymers in Designed Patterns. Nat. Nanotech. 10, 892-898.

(36) Ding, K.; Alemdaroglu, F. E.; Börsch, M.; Berger, R.; Herrmann, A. (2007) Engineering the Structural Properties of DNA Block Copolymer Micelles by Molecular Recognition. Angew. Chem. Int. Ed. 46, 1172-1175.

(37) Kwak, M.; Gao, J.; Prusty, D. K.; Musser, A. J.; Markov, V. A.; Tombros, N.; Stuart, M. C. A.; Browne, W. R.; Boekema, E. J.; ten Brinke, G. et al. (2011) DNA Block Copolymer Doing It All: From Selection to Self-Assembly of Semiconducting Carbon Nanotubes. Angew. Chem. Int. Ed. 50, 3206-3210.

(38) Vyborna, Y.; Vybornyi, M.; Rudnev, A. V.; Häner, R. (2015) DNA-Grafted Supramolecular Polymers: Helical Ribbon Structures Formed by Self-Assembly of Pyrene-DNA Chimeric Oligomers. Angew. Chem. Int. Ed. 54, 7934-7938.

(39) Vyborna, Y.; Vybornyi, M.; Häner, R. (2015) From Ribbons to Networks: Hierarchical Organization of DNA-Grafted Supramolecular Polymers. J. Am. Chem. Soc. 137, 14051-14054.

(40) Nussbaumer, A. L.; Studer, D.; Malinovskii, V. L.; Häner, R. (2011) Amplification of Chirality by Supramolecular Polymerization of Pyrene Oligomers. Angew. Chem. Int. Ed. 50, 54905494.

(41) Malinovskii, V. L.; Nussbaumer, A. L.; Häner, R. (2012) Oligopyrenotides: Chiral Nanoscale Templates for Chromophore Assembly. Angew. Chem. Int. Ed. 51, 4905-4908.

(42) Häner, R.; Garo, F.; Wenger, D.; Malinovskii, V. L. (2010) Oligopyrenotides: Abiotic, Polyanionic Oligomers With Nucleic Acid-Like Structural Properties. J. Am. Chem. Soc. 132, 7466-7471.

(43) Vybornyi, M.; Rudnev, A. V.; Langenegger, S. M.; Wandlowski, T.; Calzaferri, G.; Häner, R. (2013) Formation of Two-Dimensional Supramolecular Polymers by Amphiphilic Pyrene Oligomers. Angew. Chem. Int. Ed. 52, 11488-11493.

(44) Parolini, L.; Kotar, J.; Di Michele, L.; Mognetti, B. M. (2016) Controlling Self-Assembly Kinetics of DNA-Functionalized Liposomes Using Toehold Exchange Mechanism. Acs Nano 10, 2392-2398.

(45) Peterson, A. W.; Wolf, L. K.; Georgiadis, R. M. (2002) Hybridization of Mismatched or Partially Matched DNA at Surfaces. J. Am. Chem. Soc. 124, 14601-14607. 
(46) Qiao, W.; Chiang, H. C.; Xie, H.; Levicky, R. (2015) Surface Vs. Solution Hybridization: Effects of Salt, Temperature, and Probe Type. Chem. 51, 17245-17248.

(47) Wang, R.; Kuzuya, A.; Liu, W.; Seeman, N. C. (2010) Blunt-Ended DNA Stacking Interactions in a 3-Helix Motif. Chem. Commun. 46, 4905-4907.

(48) Woo, S.; Rothemund, P. W. (2011) Programmable Molecular Recognition Based on the Geometry of DNA Nanostructures. Nat. Chem. 3, 620-627. 


\section{TOC ILLUSTRATION}

1

2

3

4

5

6

7

8

9

10

11

12

13

14

15

16

17

18

19

20

21

22

23

24

25

26

27

28

29

30

31

32

33

34

35

36

37

38

39

40

41

42

43

44

45

46

47

48

49

50

51

52

53

54

55

56

57

58

59

60

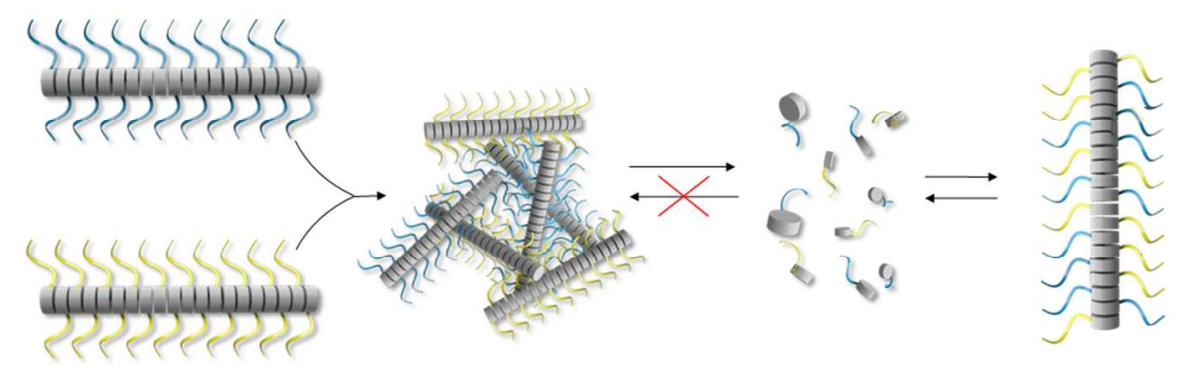




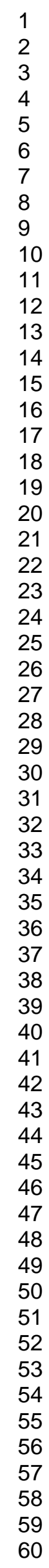

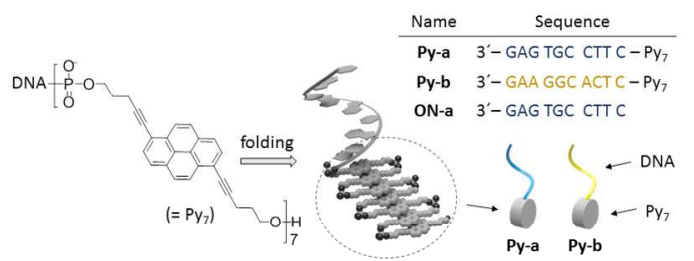

440×306mm (96 x 96 DPI) 


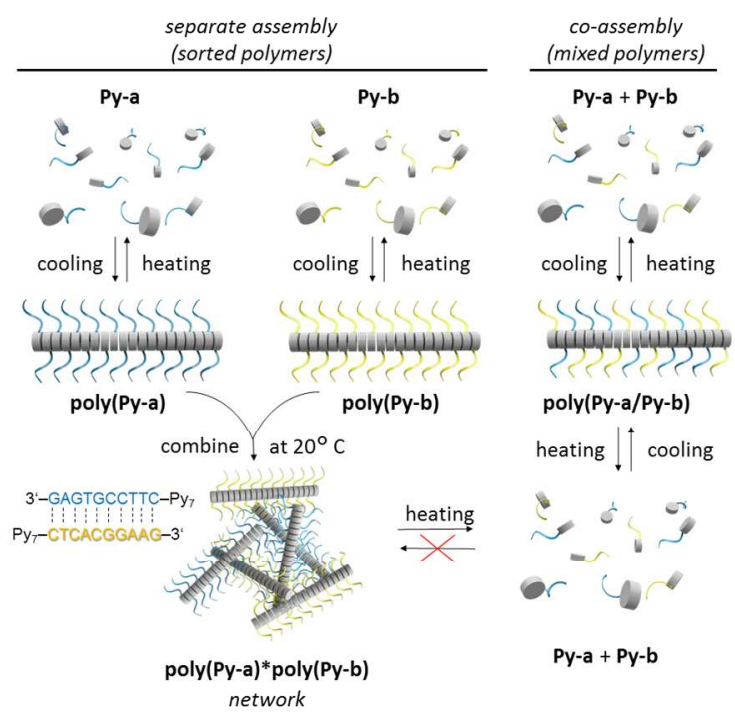

$440 \times 306 \mathrm{~mm}(96 \times 96$ DPI) 


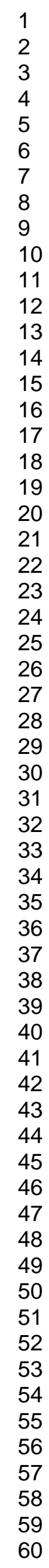

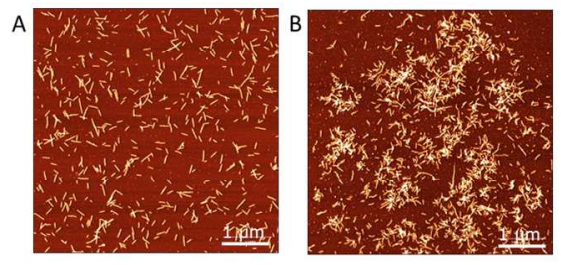

$440 \times 306 \mathrm{~mm}(96 \times 96$ DPI) 

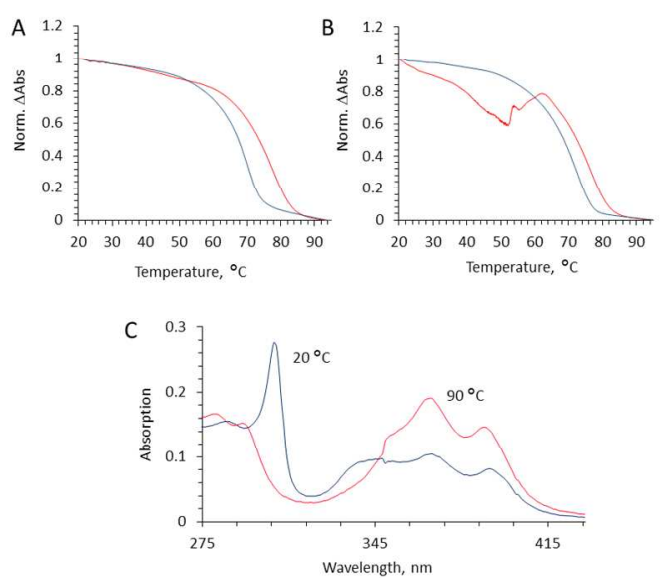

34

35

36

37

38

39

40

41

42

43

44

45

46

47

48

49

50

51

52

53

54

55

56

57

58

59

60 


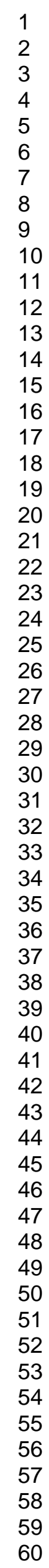

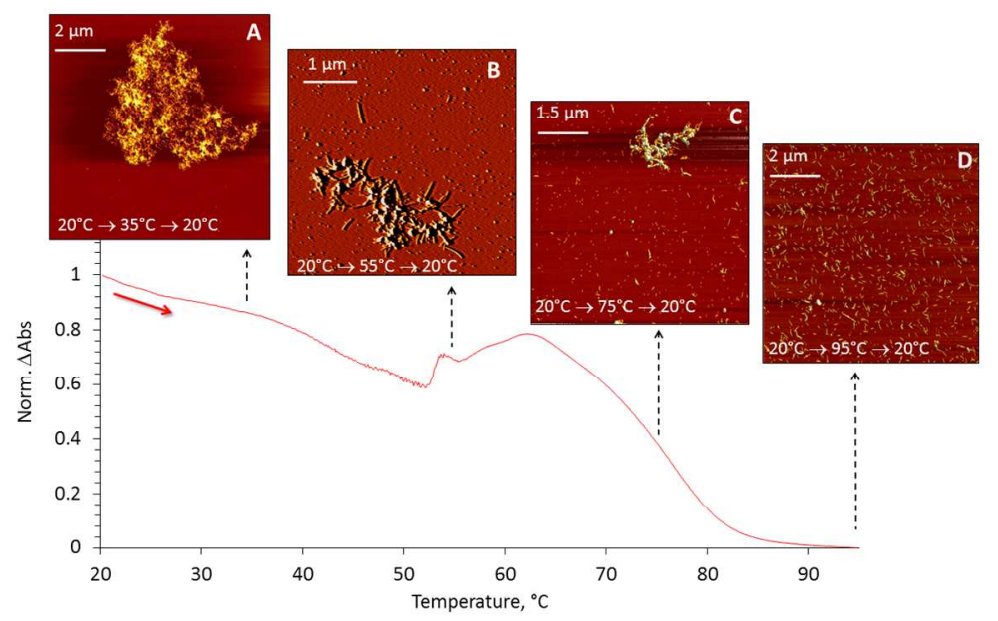

440×306mm (96 x 96 DPI) 

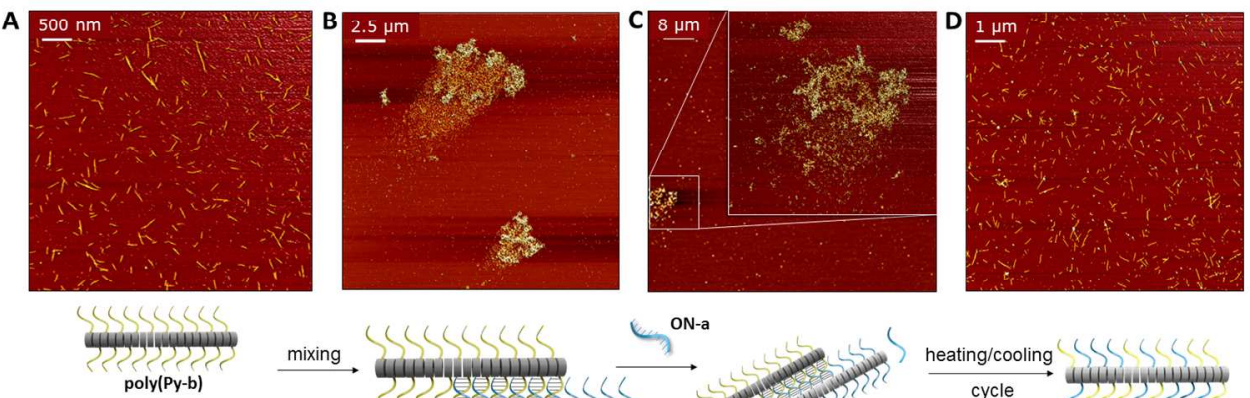

द्ये 5resetret

poly(Py-a)<smiles>[C+]1CCC1</smiles>

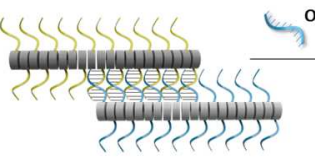

poly(Py-a)*poly(Py-b)

poly(Py-a)*poly(Py-b)+ON-a

poly(Py-a/Py-b)+ON-a

440×306mm (96 x 96 DPI) 

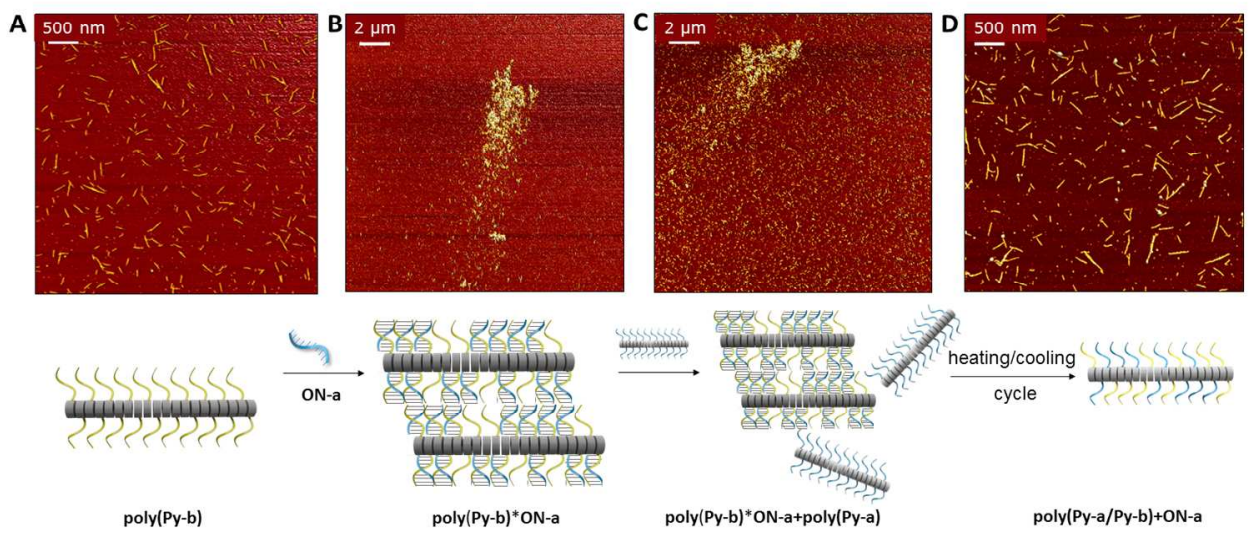

poly $(\mathrm{Py}-\mathrm{b})^{*} \mathrm{ON}-\mathrm{a}$

poly $(\mathrm{Py}-\mathrm{b})^{*} \mathrm{ON}-\mathrm{a}+$ poly$(\mathrm{Py}-\mathrm{a})$

$440 \times 306 \mathrm{~mm}(96 \times 96$ DPI $)$ 


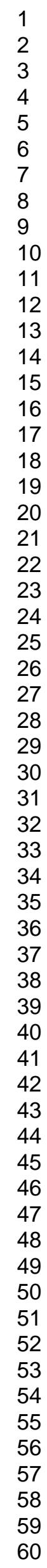

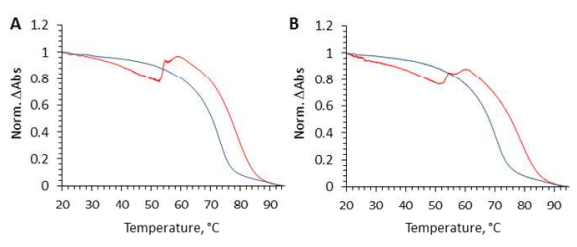

$440 \times 306 \mathrm{~mm}(96 \times 96 \mathrm{DPI})$ 


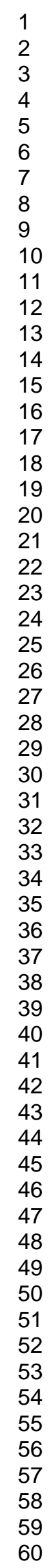

$338 \times 190 \mathrm{~mm}(96 \times 96$ DPI) 